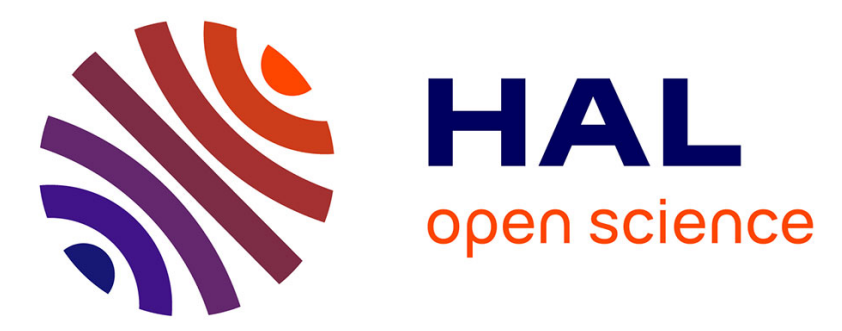

\title{
Novitates neocaledonicae I: An additionnal new species of Planchonella (Sapotaceae) endemic to the Roches de la Ouaième
}

Jérôme Munzinger

\section{- To cite this version:}

Jérôme Munzinger. Novitates neocaledonicae I: An additionnal new species of Planchonella (Sapotaceae) endemic to the Roches de la Ouaième. Phytotaxa, 2015, 201 (1), pp.71. 10.11646/phytotaxa.201.1.5 . hal-02091052

\section{HAL Id: hal-02091052 \\ https://hal.umontpellier.fr/hal-02091052}

Submitted on 5 Apr 2019

HAL is a multi-disciplinary open access archive for the deposit and dissemination of scientific research documents, whether they are published or not. The documents may come from teaching and research institutions in France or abroad, or from public or private research centers.
L'archive ouverte pluridisciplinaire HAL, est destinée au dépôt et à la diffusion de documents scientifiques de niveau recherche, publiés ou non, émanant des établissements d'enseignement et de recherche français ou étrangers, des laboratoires publics ou privés. 


\title{
Article
}

http://dx.doi.org/10.11646/phytotaxa.201.1.5

\section{Novitates neocaledonicae I: An additionnal new species of Planchonella (Sapotaceae) endemic to the Roches de la Ouaième}

\author{
JÉRÔME MUNZINGER \\ IRD, UMR AMAP, Laboratoire de Botanique et d'Écologie végétale appliquées, Herbier NOU, F-98848 Nouméa (Nouvelle-Calédonie) \\ et IRD, UMR AMAP, F-34000 Montpellier (France).email: jerome.munzinger@ird.fr
}

\begin{abstract}
A new species of Planchonella, endemic to the Roches de la Ouaième in northeastern New Caledonia, is described and illustrated. Planchonella ulfii morphologically resembles $P$. roseoloba, while molecular data indicate a closer relation to $P$. minutiflora and P. koumaciensis, with all three species belonging to a clade characterized by ridged fruits. The new species brings the total for the genus to 37 species in New Caledonia, 36 of which are endemic to the archipelago. With a single known population comprising 10 individuals, a preliminary risk of extinction assessment using the IUCN Red List criteria indicates that it is Critically Endangered due to risk of fire faced by the shrubby vegetation found of the summit crest of the Roches de la Ouaième. The level of micro-endemism found at this site is discussed.
\end{abstract}

Key words: Sapotaceae, Planchonella, Roches de la Ouaième, New Caledonia, IUCN Red List assessment, new species

\section{Introduction}

In November 2010 an expedition using the Rapid Assessment Protocol (RAP) was organized in the Mt. Panié range and the nearby Roches de la Ouaième in northeastern New Caledonia. A series of plots were established to characterize the vegetation and to contribute to the New Caledonian Plant Inventory and Permanent Plot Network (NC-PIPPN) (Ibanez et al. 2014). In parallel, general plant collecting was done in order to facilitate the identification of material recorded from inside the plots and to contribute to the overall botanical inventory of the targeted sites. Several taxa were immediately identified as potentially new to science, as indicated in a preliminary report (Munzinger et al. 2011), several of which have since been published, including Meryta rivularis Lowry (in Callmander \& Lowry II 2011: 264; Araliaceae) and Pandanus taluucensis Callmander (in Callmander \& Lowry II 2011: 268; Pandanaceae), Podonephelium pachycaule Munzinger, Lowry, Callmander \& Buerki (2013: 1118; Sapindaceae), while another, referred to in the report as 'Tapeinosperma sp. (JM3527)' was ultimately described as a new variety: Tapeinosperma tchingouense var. longipetiolatum Schmid (2012: 336; Primulaceae). A full summary of results of the RAP, including data from the plots and list of all the collections made, was recently published (Munzinger 2013).

During inventory work on the summit of the Roches de la Ouaième, fertile material was collected of a plant belonging to the genus Planchonella Pierre (1890: 34; Sapotaceae) that had first been observed sterile in 2005 (JM pers. obs.) but could not be identified at the time to a known species. This new material supported the idea that it represented a new entity, and this was confirmed when immature fruits were collected during a subsequent field trip in 2013, making it possible now to provide a detailed description of this new species. Material was also included in a recent molecular phylogenetic study (Swenson et al. 2014), which indicated that its closest relatives are $P$. minutiflora Munzinger \& Swenson (2009: 182) and P. koumaciensis Aubréville (1967: 154), although morphologically it most closely resembles P. roseoloba Munzinger \& Swenson (in Swenson et al. 2007b: 342).

Planchonella has been the subject of intensive study during the last decade as part of a thorough revision of Sapotaceae in New Caledonia. First, the genus was re-circumscribed, merging it with the previously recognized genera Albertisiella Pierre ex Aubréville (1964: 42), Bureavella Pierre (1890: 16), Iteiluma Baillon (1890: 892) and Pyriluma (Baill.) Aubréville (1967: 83), and transferring one species from Planchonella to Pichonia Pierre (1890: 22) (Swenson et al. 2007a). A proposal was then made to conserve the name Planchonella against Iteiluma and Peuceluma Baillon 
(1890: 895) (Swenson \& Morat 2008). In parallel, eight (Swenson et al. 2007b) plus three new species (Munzinger \& Swenson 2009), all endemic to New Caledonia, were described and then an identification key was provided for the 36 species recognized in the archipelago (Munzinger \& Swenson 2009), only one of which is not endemic, P. linggensis (Burck) Pierre (1890: 35) (Morat et al. 2012).

\section{Materials and methods}

Herbarium specimens of the plant collected on the Roches de la Ouaième were compared with the New Caledonian material of Planchonella at P, NOU and MPU (acronyms following Thiers 2014) and with the information presented in publications dealing with the taxonomy of New Caledonian members of Planchonella and related genera (Guillaumin 1942, 1944; Herrmann-Erlee \& van Royen 1957; van Royen 1957; Vink 1958; Aubréville 1962, 1963, 1967; Swenson et al. 2007b; Munzinger \& Swenson 2009). For the preparation of the description provided below, material was examined under a Leica S6D binocular microscope, and photos taken in the field with a Nikon D70 camera with optical macro 60 $\mathrm{mm}$ were examined. A risk of extinction assessment was conducted using the IUCN Red List criteria (IUCN 2012).

\section{Taxonomy}

Planchonella ulfii Munzinger, sp. nov. (Figs. 1, 2 \& 3)

Haec species Planchonellae roseolobae Munzinger \& Svenson similis, sed longidecurrenti imo, revoluta margine, numerosis intersecondariis nervis reticulo, minoribus crassioribusque foliis, differt.

Type:-New Caledonia, North Province, sommet des roches de la Ouaième, 900 m, 4.XI.2010, fl., Munzinger, Hequet, Vandrot, Butin, Birnbaum \& Rounds 6150 (P 00641006 ! -holotype; isotypes: NOU 034143!, S!).

Small branched shrub, reaching $2.5 \mathrm{~m}$ tall, with erect branches, young twigs ferruginous with + - persistent indument, old twigs brown-black. Leaves thick, dark green and shiny above, light green below (in fresh material), clustered toward the summit of twigs, blade obovate, $4-10 \times 2-4 \mathrm{~cm}$, with sparse trichomes when young, then quickly glabrous, petiole 15-33 mm long, $1.5 \mathrm{~mm}$ in diam., puberulent when young then glabrous, base long decurrent on petiole, margin flat or revolute in fresh material, revolute when dry, apex rounded, venation brochidodromous, extending very close to the margin (less than $1 \mathrm{~mm}$ ), midvein prominent below, flat to sometime canaliculate above, 6 to 10 pairs of secondary veins, distinct, intersecondary veins numerous, tertiary venation distinct, reticulate. Flowers 5-merous, hermaphroditic or female, borne axillary to the leaves and on the twigs just below the oldest leaves, oriented more or less toward the ground; pedicel curved downward, 2-3(-4) mm, pubescent. Sepals widely elliptic, 3-4 mm, ferruginous, the outer ones completely covered with indument on the adaxial face, the inner ones larger, lacking indument towards the membranous and ciliate margins. Corolla $4-4.5 \mathrm{~mm}$ long and wide in hermaphrodite flowers, $3.5 \mathrm{~mm}$ long and $2.5 \mathrm{~mm}$ wide in female flowers; tube $3 \mathrm{~mm}$ long, white or cream, lobes white or slightly pinkish, $1-1.25 \mathrm{~mm}$ long, \pm oblong. Stamens shorter than the corolla, yellow, filaments $\sim 1 \mathrm{~mm}$ long, anthers $\sim 1 \mathrm{~mm}$ long, staminodes triangular, as long as filaments. Ovary cylindrical, hairy, $1.5 \mathrm{~mm}$ high, $2 \mathrm{~mm}$ in diam., slightly lobed, style thick, $2 \mathrm{~mm}$ long, slightly shorter than the corolla. Fruit (immature) obovoid, ridged, apex acuminate, up to $33 \times 15 \mathrm{~mm}$ (acumen ca. $5 \mathrm{~mm}$ ), glabrous except few hairs at the base. Seeds unknown.

Distribution and Ecology:- Planchonella ulfii is only known from a single locality in the north-eastern part of New Caledonia's main island (Grande Terre) situated on the summit crest of the Roches de la Ouaième (Wayem), above $900 \mathrm{~m}$ (Fig. 3), where a population of 10 individuals was observed. The second summit of the Roches de la Ouaième, which also reaches to $900 \mathrm{~m}$ and is located slightly to the east (see Fig. 3), could not be explored.

Phenology:-Flowers have been observed in November and February, with nearly ripe fruits seen in February.

Etymology:-This new species is dedicated to my friend and colleague Ulf Swenson who has greatly contributed to systematics of New Caledonian Sapotaceae during the last decade with his revisions of Pichonia (Swenson \& Munzinger 2012) Pycnandra Bentham (in Bentham \& Hooker 1876: 658) subg. Pycnandra (Swenson \& Munzinger 2009), P. subg. Trouettia (Pierre ex Baillon) Swenson \& Munzinger (2010c: 337), P. subg. Achradotypus (Baillon) Swenson 
\& Munzinger (2010a: 188) and $P$. subg. Sebertia (Pierre ex Engler) Swenson \& Munzinger (2010b: 242), in addition to the papers on Planchonella cited above and several studies on the phylogenetics of these plants.

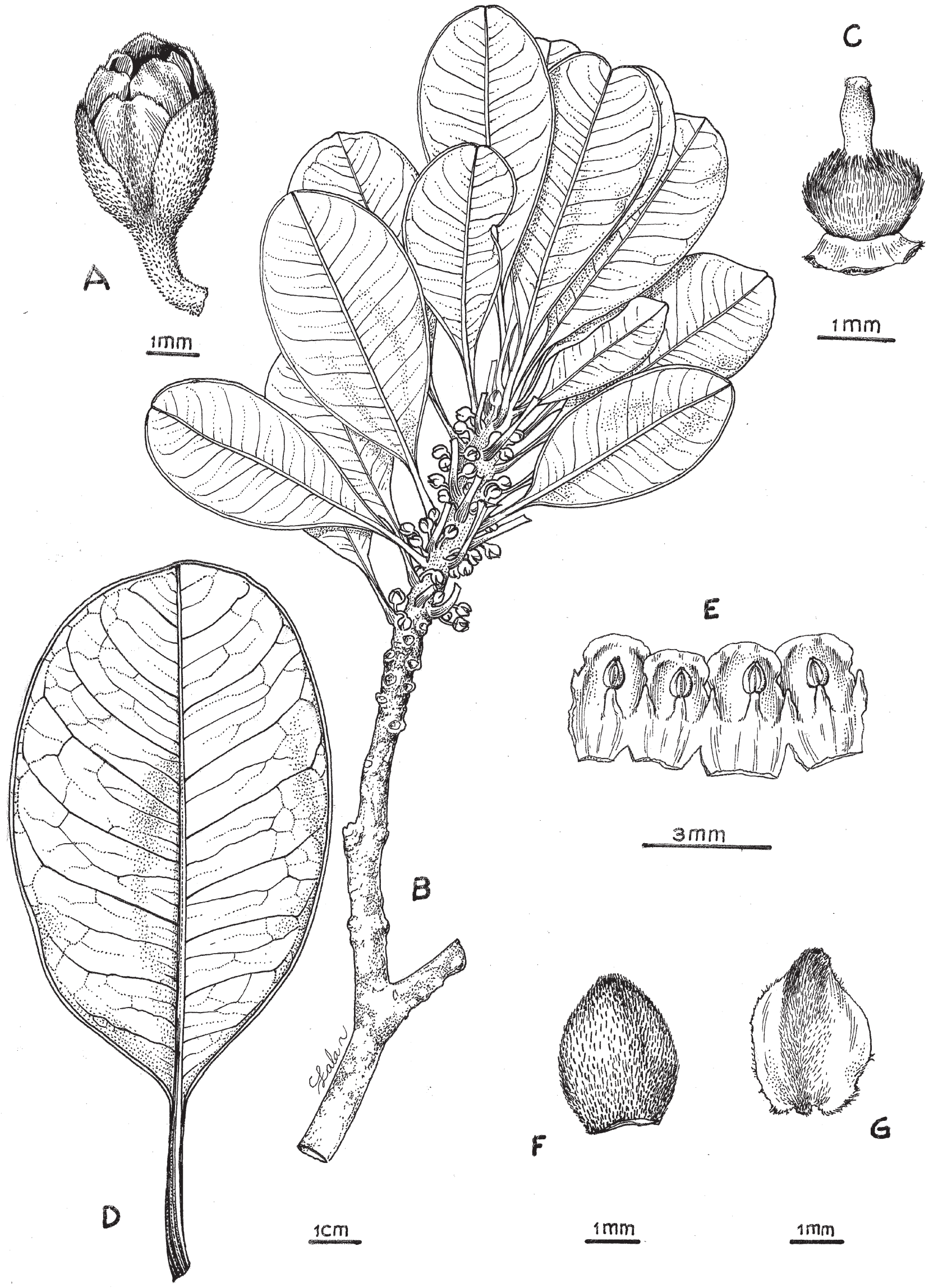

FIGURE 1. A. Floral bud. B. Flowering twig. C. Gynoecium. D. Leaf. E. Inside of the corolla with stamens and staminodes. F. Dorsal face of external sepal. G. Dorsal face of internal sepal. (A-G based on Munzinger \& al. 6150). 


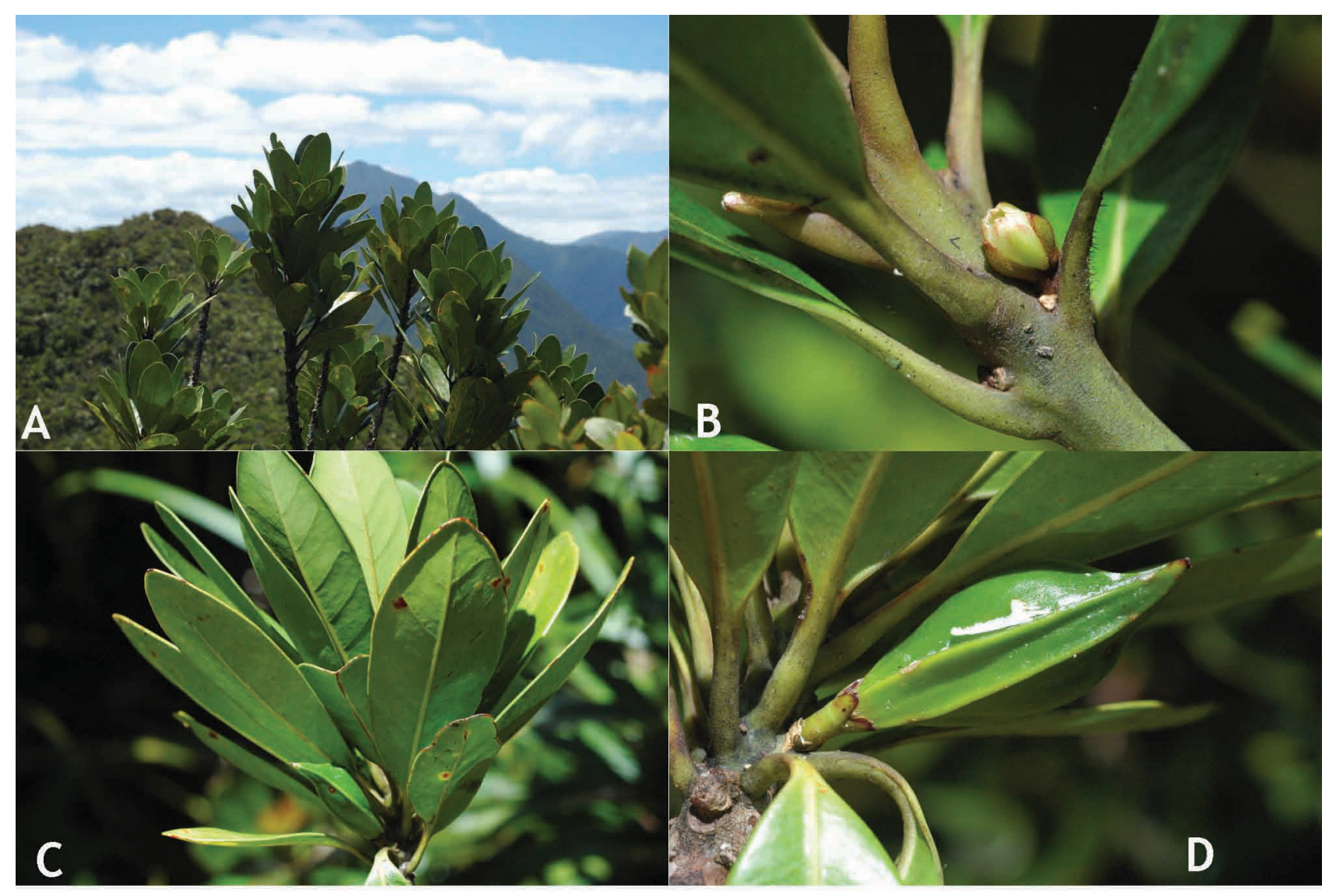

FIGURE 2. Photos of Planchonella ulfii taken in the field. A. Habit with leaves clustered toward the summit of twigs. B. Flower. C. Glabrous leaves, intersecondary veins visible, young fruit in the lower left. D. Nearly ripe ridged fruit. (A-D from Munzinger \& al. 7095, photos J. Munzinger).

Discussion:- Planchonella ulfii belongs to clade D1 as defined by Swenson et al. (2007b; 2014), a placement that is consistent with its ridged fruit (Fig. 2C, D). The plant resembles $P$. roseoloba Munzinger \& Swenson in its morphology, but differs in its smaller and thicker leaves with revolute margin, reticulate venation, numerous intersecondary veins and long-decurrent base (in herb. and see Fig. $2 \mathrm{C}$ ). These two species also differ in their habit and ecology: $P$. ulfii is a shrub restricted to the summit of the Roches de la Ouaième, above $900 \mathrm{~m}$, in low shrubby vegetation, whereas P. roseoloba is a tree occurring in dense humid forest at 300-700 m elevation.

Some flowers of Planchonella ulfii appear morphologically to be hermaphrodite whereas others are female (with staminodes rather than fertile stamens), a situation suggesting that the species may be gynomonoecious, as observed in several other new Caledonian members of the genus (Méndez \& Munzinger 2010).

Conservation status:- With a single known population of 10 individuals confined to forest situated along a crest that is subject to anthropogenic fires that are regularly set from the base of the cliffs, Planchonella ulfii is here assigned a preliminary conservation status of Critically Endangered (CR, D1) using the IUCN Red List criteria (IUCN 2012).

Additional specimens examined (Paratypes):- New Caledonia, North Province, sommet des roches de la Ouaième, 3.II.2013 (fl., fr.), Munzinger, Swenson, Isnard \& Butin 7095 (BRI!, MO!, MPU!, NOU!, P!, S!).

\section{Micro-endemism on the Roches de la Ouaième increased?}

Bradford \& Jaffre (2004) were the first to call attention to the conservation importance of the Roches de la Ouaième, citing no fewer than 12 micro-endemics. A more recent study pointed to a total of 17 very rare species present in this locality, which was classified as a Hotspot of Plant Narrow Endemism (HPNE) by Wulff et al. (2013). Planchonella ulfiii could be regarded as the $18^{\text {th }}$ species on this list were it not for the fact that Pycnandra ouaiemensis Swenson \& Munzinger (2010a: 210), which was thought to be restricted to the Roches de la Ouaième, was recently recorded farther north in the Mt. Panié range during the RAP, adding a second locality for this species (Munzinger 2013), and suggesting that at least some micro-endemism may be an artifact of inadequate exploration in the surrounding area. 


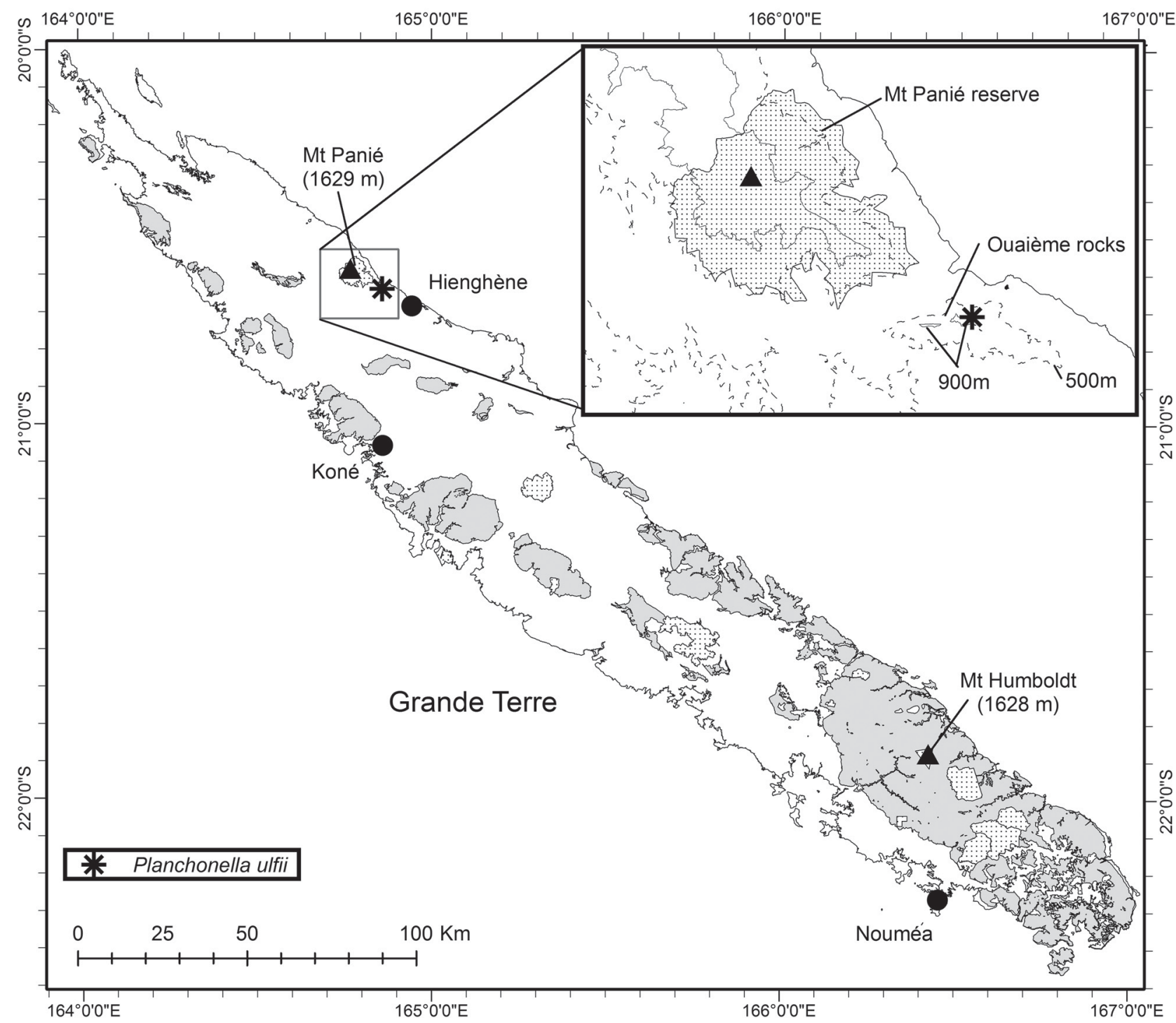

FIGURE 3. Distribution of Planchonella ulfii. Grey represents ultramafic substrates, dotted lines delineate protected areas, dashed lines show the $500 \mathrm{~m}$ elevational contour, and continuous lines the $900 \mathrm{~m}$ contour.

\section{Toward a series of novelties from New Caledonia}

Guillaumin's Flore Analytique et Synoptique de la Nouvelle-Calédonie (1948) provided identification keys for all of the plants known to occur in the territory at the time, but lacked descriptions and was quickly regarded as inadequate. Indeed, less than twenty year later the first volume of the new Flore de la Nouvelle-Calédonie \& Dépendances was published (Aubréville et al. 1967-), treating individual families and including species descriptions, maps, line drawings and citations of material examined. To date about $52 \%$ of New Caledonia's native flora has been treated (based on Florical (Morat et al. 2012)), which might lead one to think that this series is nearing completion. However, this is most definitely not the case, as demonstrated clearly by the situation with Sapotaceae, which were initially treated nearly fifty years ago by Aubréville (1967), who recognized a total of 80 species, but in which about 40 new species have been identified during the last decade, most of which have now been described. Similarly, many novelties or corrections have been published in much more recently treated families, pointing to the fact that many new discoveries are still being made. For example, a new species of Patersonia Brown (1807: 1041) (Iridaceae) was recently described (Goldblatt et al. 2011), only two decades after the original treatment (Goldblatt 1990) in which only introduced taxa were recorded. Another example results from invaluable information obtained from the cultivation of plants in greenhouses, which revealed the need to resurrect the name Oxera pancheri Dubard (1906: 716) (Gâteblé \& Munzinger 2012), considered to be a synonym of $O$. sulfurea Dubard (1906: 716) in the treatment of Labiatae in the Flore (Mabberley \& de Kok 2004). In order to facilitate the publication of the many novelties that will no doubt be forthcoming, a series is being 
initiated here. A second contribution will soon follow, describing a new species of Acropogon Schlechter (1906: 186) (Malvaceae) (Callmander et al., 2015).

\section{Acknowledgements}

This work was conducted under the "Convention Province Nord / IRD №10C319, Relative à la contribution au composant botanique du programme d'évaluation rapide de la biodiversité du mont Panié". We thank Jean-Jérôme Cassan (DDEE) and the team at the herbarium at IRD Nouméa (NOU) for help. Jacques Florence (IRD) provided the Latin translation of the diagnosis, and Roger Lala Andriamiarisoa (Missouri Botanical Garden, Antananarivo) provided the fine illustration. Thanks to the organizers of the RAP, Romain Franquet (Association Dayu Biik) and François Tron (Conservation International), and to the other members of the botanical team (Philippe Birnbaum, Jean-Pierre Butin, Martin Callmander, Vanessa Hequet, Pete Lowry, Isaac Rounds, Mathias Teimpouene, Thomas Teimpouene, Hervé Vandrot) as well as those who participated in the other components of the RAP, Jean-Jacques Folger, Gabriel Teimpouene and especially Maurice Wanguene. Thanks also to Sandrine Isnard and Ulf Swenson for their enthusiastic participation in field work, and Pete Lowry for English correction and advice.

\section{References}

Aubréville, A. (1962) Notes sur les Sapotacées de la Nouvelle-Calédonie. Adansonia 2: 172-199.

Aubréville, A. (1963) Notes sur les Poutériées Océaniennes (Sapotacées). Adansonia 3: 327-335.

Aubréville, A. (1964) Validation du genre Albertisiella Pierre. Adansonia 4: 42.

Aubréville, A. (1967) Sapotacées. In: Aubréville, A. (Ed.) Flore de la Nouvelle-Calédonie et Dépendances 1. Muséum National d'Histoire Naturelle. Paris, pp. 1-168.

Aubréville, A., Leroy, J.-F., MacKee, H.S. \& Morat, P. (Eds.) (1967-) Flore de la Nouvelle-Calédonie et Dépendances. Muséum National d'Histoire Naturelle, Paris.

Baillon, H. (1890) Observations sur les Sapotacées de la Nouvelle-Calédonie. Bulletin Mensuel de la Société Linnéenne de Paris 2: 889-896.

Bentham, G. \& Hooker, J.D. (1876) Genera Plantarum ad exemplaria imprimis in herbariis Kewensibus seivata definita. Reeve \& co., London.

Bradford, J. \& Jaffré, T. (2004) Plant species microendemism and conservation of montane maquis in New Caledonia: two new species of Pancheria (Cunoniaceae) from Roche Ouaï̀me. Biodiversity and Conservation 13: 2253-2273. http://dx.doi.org/10.1023/B:BIOC.0000047901.33761.3c

Brown, R. (1807). Patersonia sericea. In: Curtis’s Botanical Magazine. 1041 pp.

Callmander, M.W. \& Lowry II, P.P. (2011). Deux nouvelles espèces du Massif du Panié (Nouvelle-Calédonie): Meryta rivularis Lowry (Araliaceae) et Pandanus taluucensis Callm. (Pandanaceae). Candollea 66: 263-272.

Callmander, M.W., Munzinger, J., Buerki, S. \& Lowry II, P.P. (2015). Novitates neocaledonicae II: Acropogon moratianus (Malvaceae, Sterculieae): a rare and threatened new species from New Caledonia. [sér. 3] Adansonia.

Dubard, M. (1906) Révision du genre Oxera (Verbénacées). Bulletin de la Société Botanique de France 53: 705-717. http://dx.doi.org/10.1080/00378941.1906.10831920

Gâteblé, G. \& Munzinger, J. (2012) Réhabilitation de Oxera pancheri Dubard (Labiatae), espèce menacée de la Nouvelle-Calédonie. [Sér. 3] Adansonia 34: 375-386. http://dx.doi.org/10.5252/a2012n2a11

Goldblatt, P. (1990) Iridaceae. In: Morat, P. \& MacKee, H.S. (Eds.) Flore de la Nouvelle-Calédonie et Dépendances 16. Muséum National d'Histoire Naturelle. Paris, pp. 119-124.

Goldblatt, P., Manning, J.C., Munzinger, J. \& Lowry II, P.P. (2011) A new family and new species for the flora of New Caledonia: Patersonia neocaledonica (Iridaceae: Patersonioideae), from the Mt. Humboldt massif. [sér. 3] Adansonia 33: 201-208. http://dx.doi.org/10.5252/a2011n2a4

Guillaumin, A. (1942) Matériaux pour la flore de la Nouvelle-Calédonie. LXXI. Revue et critique des Sapotacées. Bulletin de la Société Botanique de France 89: 222-224.

http://dx.doi.org/10.1080/00378941.1942.10839785 
Guillaumin, A. (1944) Matériaux pour la flore de la Nouvelle-Calédonie. LXXXII. Sapotacées nouvelles. Bulletin de la Société Botanique de France 91: 68-72.

http://dx.doi.org/10.1080/00378941.1944.10834326

Guillaumin, A. (1948) Flore analytique et synoptique de la Nouvelle-Calédonie, phanérogames. Office de la Recherche Scientifique Coloniale, Paris.

Herrmann-Erlee, M.P.M. \& van Royen, P. (1957) Revision of the Sapotaceae of the Malaysian area in a wider sense IX) Pouteria Aublet. Blumea 8: 452-509.

Ibanez, T., Munzinger, J., Dagostini, G., Hequet, V., Rigault, F., Jaffré, T. \& Birnbaum, P. (2014). Structural and floristic characteristics of mixed rainforest in New Caledonia: New data from the New Caledonian Plant Inventory and Permanent Plot Network (NC-PIPPN). Applied Vegetation Science 17: 386-397. http://dx.doi.org/10.1111/avsc.12070

IUCN (2012) IUCN Red List Categories and Criteria. Version 3.1. Second edition. IUCN Species Survival Commission, IUCN, Gland, Switzerland and Cambridge, UK.

Mabberley, D.J. \& de Kok, R.P.J. (2004) Labiatae. In: Morat P. (Ed.) Flore de la Nouvelle-Calédonie et Dépendances 25. Muséum National d'Histoire Naturelle. Paris, pp. 20-141.

Méndez, M. \& Munzinger, J. (2010) Planchonella, first record of gynomonoecy for the family Sapotaceae. Plant Systematics and Evolution 287: $65-73$.

http://dx.doi.org/10.1007/s00606-010-0290-5

Morat, P., Jaffré, T., Tronchet, F., Munzinger, J., Pillon, Y., Veillon, J.-M. \& Chalopin, M. (2012). Le référentiel taxonomique Florical et les caractéristiques de la flore vasculaire indigène de la Nouvelle-Calédonie. [Sér. 3] Adansonia 34: 177-219. http://dx.doi.org/10.5252/a2012n2a1

Munzinger, J. (2013) Inventaire botanique du massif du Panié et des roches de la Ouaième, Province Nord, Nouvelle-Calédonie. In: Tron, F., Franquet, R., Larsen, T.H. \& Cassan, J.-J., Evaluation rapide de la biodiversité du massif du Panié et des Roches de la Ouaième, Province nord, Nouvelle-Calédonie. RAP Bulletin of Biological Assessment 65. Conservation International. Arlington, VA, USA, pp. 45-86.

Munzinger, J., Birnbaum, P., Butin, J.-P., Callmander, M., Hequet, V., Lowry II, P.P. \& Vandrot, H. (2011) Rapport préliminaire - RAP dans la massif du Mont Panié, Nouvelle-Calédonie. Institut de recherche pour le Développement, Nouméa, 18 pp.

Munzinger, J., Lowry II, P.P., Callmander, M. \& Buerki, S. (2013). A Taxonomic Revision of the Endemic New Caledonian Genus Podonephelium Baillon (Sapindaceae). Systematic Botany 38: 1105-1124. http://dx.doi.org/10.1600/036364413X674814

Munzinger, J. \& Swenson, U. (2009) Three new species of Planchonella (Sapotaceae) with a dichotomous and an online key to the genus in New Caledonia. [sér. 3] Adansonia 31: 175-189.

http://dx.doi.org/10.5252/a2009n1a12

Pierre, J.B.L. (1890) Notes Botaniques Sapotacées. Librairie des Sciences Naturelles, Paris. http://dx.doi.org/10.5962/bhl.title.10315

Schlechter, R. (1906) Beiträge zur Kenntnis der Flora von Neu-Kaledonien. [heft 1] Botanische Jahrbücher für Systematik and Pflanzengeographie 39: 1-274.

Schmid, M. (2012) Contribution à la connaissance des Primulaceae (ex Myrsinaceae) de Nouvelle-Calédonie. III. Les genres Tapeinosperma Hook.f. et Mangenotiella gen. nov. [sér. 3] Adansonia 34: 279-341. http://dx.doi.org/10.5252/a2012n2a7

Swenson, U., Bartish, I. \& Munzinger, J. (2007a) Phylogeny, diagnostic characters, and generic limitation of Australasian Chrysophylloideae (Sapotaceae, Ericales): Evidence from ITS sequence data and morphology. Cladistics 23: 201-228.

http://dx.doi.org/10.1111/j.1096-0031.2006.00141.x

Swenson, U. \& Morat, P. (2008) (1851) Proposal to conserve the name Planchonella nom. cons. against the additional names Iteiluma and Peuceluma (Sapotaceae). Taxon 57: 1013-1014.

Swenson, U. \& Munzinger, J. (2009). Revision of Pycnandra subgenus Pycnandra (Sapotaceae), a genus endemic to New Caledonia. Australian Systematic Botany 22: 437-465. http://dx.doi.org/10.1071/SB09029

Swenson, U. \& Munzinger, J. (2010a). Revision of Pycnandra subgenus Achradotypus (Sapotaceae) with five new species from New Caledonia. Australian Systematic Botany 23: 185-216. http://dx.doi.org/10.1071/SB09049

Swenson, U. \& Munzinger, J. (2010b). Revision of Pycnandra subgenus Sebertia (Sapotaceae) and a generic key to the family in New Caledonia. [Sér. 3] Adansonia 32: 239-249.

http://dx.doi.org/10.5252/a2010n2a5 
Swenson, U. \& Munzinger, J. (2010c) Taxonomic revision of Pycnandra subgenus Trouettia (Sapotaceae) with six new species from New Caledonia. Australian Systematic Botany 23: 333-370.

http://dx.doi.org/10.1071/SB10025

Swenson, U. \& Munzinger, J. (2012). Revision of Pichonia (Sapotaceae) in New Caledonia. Australian Systematic Botany 25: $31-48$. http://dx.doi.org/10.1071/SB11027

Swenson, U., Munzinger, J. \& Bartish, I. (2007b) Molecular phylogeny of Planchonella (Sapotaceae) and eight new species from New Caledonia. Taxon 56: 329-354.

Swenson, U., Nylinder, S. \& Munzinger, J. (2014). Sapotaceae biogeography supports New Caledonia being an old Darwinian island. Journal of Biogeography 41: 797-809. http://dx.doi.org/10.1111/jbi.12246

Thiers, B. (2014) Index Herbariorum: a global directory of public herbaria and associated staff. Available from: http://sweetgum.nybg. org/ih/.

van Royen, P. (1957) Revision of the Sapotaceae of the Malaysian area in a wider sense VII. Planchonella Pierre. Blumea 8: $235-445$.

Vink, W. (1958) Revision of the Sapotaceae of the Malaysian area in a wider sense. XIII. Chrysophyllum L. Blumea 9: 21-74.

Wulff, A.S., Hollingsworth, P.M., Ahrends, A., Jaffré, T., Veillon, J.-M., L’Huillier, L. \& Fogliani, B. (2013). Conservation Priorities in a Biodiversity Hotspot: Analysis of Narrow Endemic Plant Species in New Caledonia. Plos One 8: e73371.

http://dx.doi.org/10.1371/journal.pone.0073371 